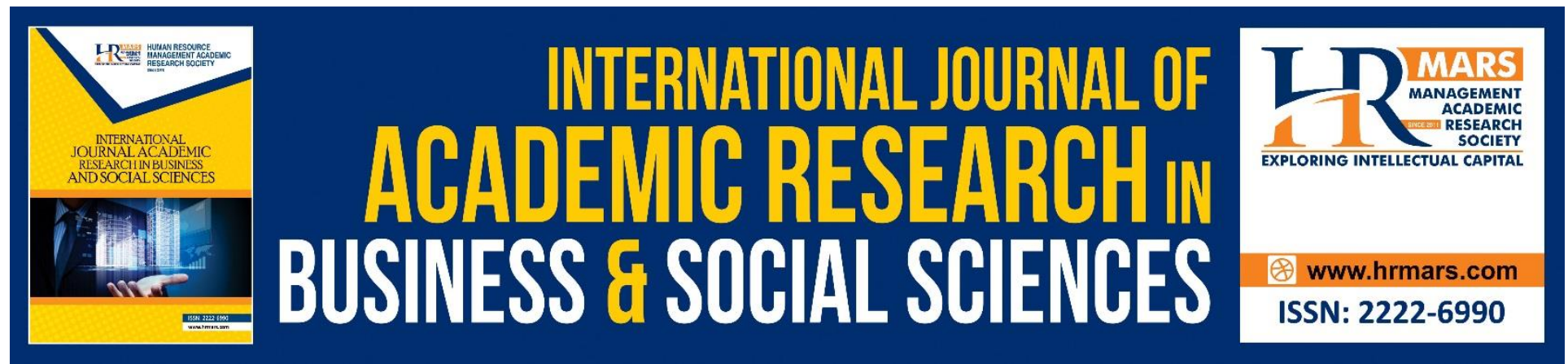

\title{
The Findings of HM-Study Skills Review Based on Cognitive Behavioral Therapy Small Group among High School Students in Malaysia
}

Roslan Ahmad Fuad, Mohamad Aziz Shah Mohamed Arip, Fauziah Sa'ad

To Link this Article: http://dx.doi.org/10.6007/IJARBSS/v9-i3/5807

DOI: $10.6007 /$ IJARBSS/v9-i3/5807

Received: 27 Jan 2019, Revised: 10 Feb 2019, Accepted: 27 Feb 2019

Published Online: 22 March 2019

In-Text Citation:(Fuad, Arip, \& Sa'ad, 2019)

To Cite this Article: Fuad, R. A., Arip, M. A. S. M., \& Sa'ad, F. (2019). The Findings of HM-Study Skills Review Based on Cognitive Behavioural Therapy Small Group among High School Students in Malaysia. International Journal Academic Research Business and Social Sciences, 9(3), 1432 -1446

Copyright: (C) 2019 The Author(s)

Published by Human Resource Management Academic Research Society (www.hrmars.com)

This article is published under the Creative Commons Attribution (CC BY 4.0) license. Anyone may reproduce, distribute, translate and create derivative works of this article (for both commercial and non-commercial purposes), subject to full attribution to the original publication and authors. The full terms of this license may be seen at: http://creativecommons.org/licences/by/4.0/legalcode

Vol. 9, No. 3, 2019, Pg. 1432 - 1446

http://hrmars.com/index.php/pages/detail/IJARBSS

JOURNAL HOMEPAGE

Full Terms \& Conditions of access and use can be found at http://hrmars.com/index.php/pages/detail/publication-ethics 


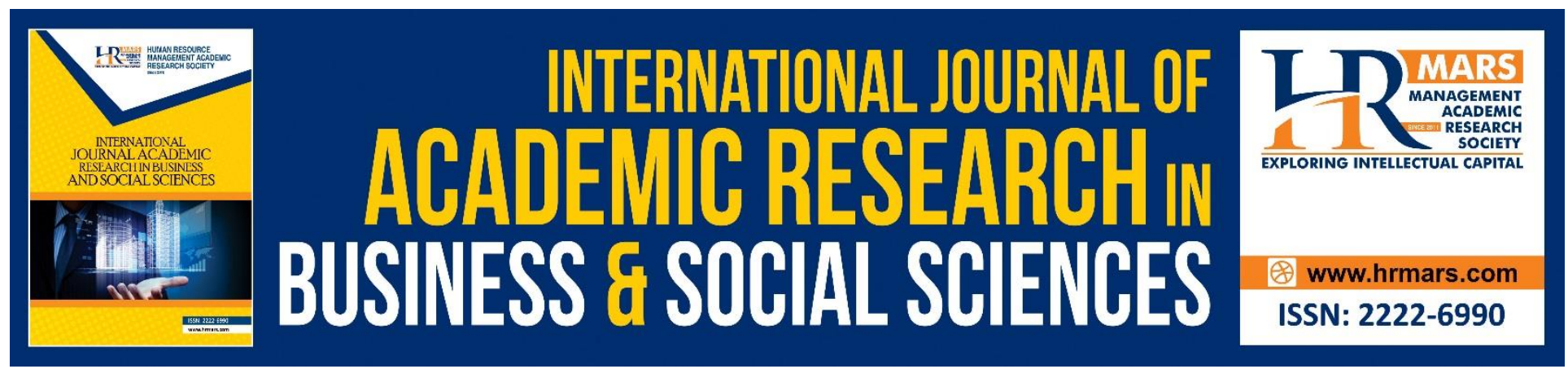

\title{
The Findings of HM-Study Skills Review Based on Cognitive Behavioural Therapy Small Group among High School Students in Malaysia
}

\author{
Roslan Ahmad Fuad, Mohamad Aziz Shah Mohamed Arip, \\ Fauziah Sa'ad
}

Department of Psychology and Counselling, Faculty of Human Development (FHD), Sultan Idris Educational University, 35900 Tanjong Malim, Perak, Malaysia

\begin{abstract}
This study aims to examine the findings of the HM Learning-Skills Module findings based on the Cognitive Behavioral Therapy Approach on Learning Skills in the Student Circle. This study is an experimental study. The study was conducted in two secondary schools in the district of Kuala Kangsar, Malaysia. A total of 60 respondents were involved in this study, 30 respondents in three smaller groups were divided equally $(n 1=10, n 2=10$ and $n 3=10)$ in the treatment groups and the rest $(n=30)$ involved in the control group. The Lesson Skills Study Group subjects follow the 10 session of the weekly HM Study Skills Module which focuses on the seven subscales of the study available in HM-learning skills, Self-Motivation, Self-Management and Time, listening skills, Mastering the Vocabulary, note-taking skills, learning skills from textbooks, and Examination Skills. Data were analyzed using descriptive analysis, MANOVA at significance level $p<0.05$ (significant at $95 \%$ level). The results of the study shows that there is no significant correlation between all the null hypotheses and this means that all the null hypotheses are accepted in this study. The HM-Learning Skills Module has implications for the field of Guidance and Counseling, the practice of Guidance and Counseling in schools and the study of Experienced Learning Experience models in transforming and enhancing student behavior towards enhancing the level of learning skills as well as suitable for future use. In conclusion, the findings show that the HM Learning-Skills module is effective in improving the learning skills as well as of the subject. The findings also found that the Learning Skills Small Group Study had an impact on the improvement of students in the learning skills.

Keywords: HM Learning-Skills Module, Cognitive Behavioral Therapy, Small Group Guiding Skills Module, Treatment Groups and Control Group.
\end{abstract}




\section{Introduction}

In learning skills, some of the techniques introduced by Robinson (1946) such as the SQ3R technique that emphasize the understanding of high-level thinking are useful in helping students to understand reading materials and combined with the skills and techniques found in Behavioral Cognitive Therapy is the skill of building positive thinking and overcoming negative thinking towards reading. Hence, with some of these skills of course the importance of reading to be felt as something important in the student so they can change the habit of reading.

In Cognitive Behavioral Therapy (CBT), Overgeneralising: Avoiding the Part / Whole Error as stated by Branch (2010) means the individual or group assumes that problem solving is the same as just looking at a problem solving course. In fact, this is a misconception that a lot of students are preventing learning from serious learning skills and this perception also causes students to drift away and easily lose the cause when they discover the deadlock when they learn and create a sense of boredom. Hence, it is important for students to get rid of the boredom of the lessons being faced and to be wise using various techniques in solving problems in learning. Thus, CBT based learning skills are the most appropriate way to overcome the problem of boredom because with the diversity of techniques and strategies designed as students will be taught on how to improve Self-Motivation, Self-Management and Time, listening skills, Mastering the Vocabulary, note-taking skills, learning skills from textbooks, and Examination Skills. Hence, with the diversity of techniques combined with the CBT technique will definitely get rid of boredom and students will find that there are various ways to solve the problem.

This study also focuses on a CBT module that focuses on attitudes and behavior change from negative to positive through change of student thought. Hence, as a group guidance intervention, the Module of the Learning Cognitive Behavioral Learning Module is based on the Hm Learning Skills Theory introduced by Wilenzick (1990). This theory emphasizes the strengths and weaknesses of the students as well as changes in behavior and how students can adjust their behavior towards a better way to learn. Interestingly, this theory is combined with CBT that focuses on changing negative behavior to positive through individual thinking changes which in turn leads to behavioral change and emotion. Hence, the Learning Skills Group Module focuses on strengths and weaknesses as well as how students can tailor positive negative thinking and know better learning goals to help them to devise and continue their learning plans as suggested by the West Virginia Department (2015) and use them in a better and effective way.

The conclusion is that each individual is believed to be capable of solving their own problems, the only problem is that they still need help and guidance from others to solve them. Likewise with learning. Students are said to have problem in enhancing themselves in learning because they do not get good help and guidance from others. Hence, this module is expected to provide guidance for teachers to guide students in facing problems in schools. Therefore, it is undeniable that learning skills are related to the success of a student.

\section{Research Objective}

Analyze whether there are significant differences in pre-test min size and post-test dependent variables Learning Skills Treatment compared to the control group.

b. To study whether there is a significant difference in the pre-test min size and post-test dependent variables to the sub-scale of Learning Skills namely Self-Motivation, Self-Management 
and Time, listening skills, Mastering the Vocabulary, note-taking skills, learning skills from textbooks, and Examination Skills treatment groups compared to control groups.

\section{Hypothesis study}

This study is an experimental form to test the effect of learning skills modules on learning skills among secondary school students based on cognitive-behavioral theory (CBT).

\section{Null Hypothesis 1}

There was no significant difference in pre-test mean measurements and post-test variables dependent Learning Skills treatment groups compared to the control group.

Through the hypothesis, the researcher has developed several hypotheses based on the subscales of each of the main variables of this study. The details of the pre-test and post-test min score tests were tested on the effectiveness of the treatment with t-test analysis and the twoway MANOVA Analysis Test. Among the Hypotheses are as set out below:

Null Hypothesis 1.1:

There is no significant difference in pre-test min and post dependent enabling tests to the experimental group's learning skills compared to the control group.

The Learning Skills Concept is the main dependent variable in this study. Hence, the researcher also examines seven subscales of the learning skills concept based on the HM-Learning Skills Inventory questionnaire. Hence, the side hypothesis of Hypothesis 1.1.1 to 1.1.7 is formed in this study.

\section{Null Hypothesis 1.1}

There is no significant difference in pre-test min and post Self-Motivation, Self-Management and Time, listening skills, Mastering the Vocabulary, note-taking skills, learning skills from textbooks, and Examination Skills subs-scales of experimental group compared to control group

1.1.1 There is no significant difference of Self-Motivation in the pre-test size and the experimental group's test compared to the control group.

1.1.2 There is no significant difference of Self-Management and Time in the pre measurements of the pretest and the experimental test of the group compared to the control group.

1.1.3 There is no significant difference of listening skills in the pre measurements of pretest and experimental groups of compared to the control group.

1.1.4 There is no significant difference of Mastering the Vocabulary in the pretest size and the experimental group test compared to the control group.

1.1.5 There is no significant difference of note-taking skills in the pre measurements of the pretest and the experimental test compared to the control group.

1.1.6 There is no significant difference learning skills from textbooks in pretest size and test test compared with control group. 
INTERNATIONAL JOURNAL OF ACADEMIC RESEARCH IN BUSINESS AND SOCIAL SCIENCES

Vol. 9, No. 3, March, 2019, E-ISSN: 2222-6990 @ 2019 HRMARS

1.1.7 There is no significant difference of Examination Skills in the size of the pretest and experimental test after being compared with the control group.

\section{The HM Learning Skills Theory Framework}

The HM-Learning Skills Theory is the main theory and is the basis of this study. Based on Wilenzick (1990), the real purpose of this study was to help students identify strengths and weaknesses in terms of their learning skills. The students' habits in learning process is also viewed and studied. This suggests that it is important for students to understand and know exactly what their strengths and weaknesses are, but they are not aware of their existence as stated by Brunner (2014b). After knowing the strengths and weaknesses of the self, then students will try to overcome their weaknesses using all the forces they have.

There are seven subscales measured in this study, Self Motivation, Self-Management and Time Management Skills, Listening Skills, Vocabulary Mastering, Notes Writing Skills, Learning Skills from Textbooks and Exam Skills.

Thus, Atkinson (1974) and McClelland $(1961,1965,1985)$ state that Motivation is a tendency to produce something and that Motivation is an achievement that depends on the motive, the motive for achieving success and motives to avoid failure. Both of these motives are mutually interrelated as they are seen as opposed to each other. So, for this reason the individual started acting. Drucker (1966), time management based on the assumption that activity records information about time and self-use, managing and distributing time and adapting it to oneself can help someone to use time efficiently. In addition, Macan (1990) sees time management as a contract that contains four dimensions i.e. 1). Goals and priorities, 2). The tendency to love the organization, 3). Mechanics and 4). Response to self in controlling the use of time. Listening Skills according to Barker (1971) is an active process and the word 'hear' itself means an active process. Active hearing involves listening process with the aim of understanding, remembering, evaluating and criticizing is more appropriate and practical. Mastering the Vocabulary means getting the meaning of a word out of context, while mastering the Vocabulary in terms of the individual is a set of known words in a language. Normally, it is also 'all the words that are known and used by someone. Knowing the word, however to know it is not as easy as it is thought to be because there are many things to learn and to know. It is also used as a tool to measure the level of mastery of individual words (Cambridge's Dictionary Online). Sketching Skills Mc Crimmon (1976) notes that a writing activity does not occur in an empty space because it often has the purpose of communicating or linking a person's message, appeal, information or idea. Learning from Textbooks is a printable artifact and bound by the rules set by an organization for each year or the Robinson (1978). The Munchnick and Munchnick (2011) Exam Skills Ideas have divided the exams that are preparations for exam classes, exam tips, taking exams and what to do after the exam but they do not run away from a form of assessment to measure understanding, memory, mastery, skills and abilities.

\section{The Model of the Construction Model}

Conceptual Framework HM Theoretical Module Construction Model Heron (1999)

Description of the conceptualized framework of the Heron Experience Learning Cycle Model Heron (1999). 
INTERNATIONAL JOURNAL OF ACADEMIC RESEARCH IN BUSINESS AND SOCIAL SCIENCES Vol. 9, No. 3, March, 2019, E-ISSN: 2222-6990 ㄷ 2019 HRMARS

The SGLS intervention processes were formulated based on Cognitive Behavioral Therapy (CBT) Models as described earlier. For this purpose, then figure 1 is referred to. It explains the impact and how the implementation of this study is done.

A total of 60 students were selected from two selected schools. Each school consists of 30 students. Ten students for each study group. The students are divided into 3 groups; the group 30 people in the Small Group Learning Skills which are further divided into three groups. The control group was consist of 30 students. Three small groups run in 10 sessions involving 10 students in each group. Treatment is carried out for 10 weeks by a counselor for each group and so is the big group run by a counselor in a group of 30 students also involving the same number of sessions with small groups.

Hence, for the purpose of applying the Experience Learning Cycle Module in SGLS, there are 10 treatment group sessions used to view the increase of Learning Skills- Cognitive Behavioral Therapy among high school students. Explanation about Experience Learning Cycle Model begins from the Phase of Understanding and Understanding of Images.

In the understanding of the Conceptual and image phase, the students are explained with the key concepts contained in the module so that they will have a clear understanding of the concepts and can imagine the journey of the session they will go through. Understanding these concepts and images are important to understand because with that the students will have easy understanding and will then be able to apply the knowledge they will gain in the session that they are going through. Among the concepts to be explained are matters relating to learning skills, CBT concepts, ABC's concepts found in CBT and the concepts contained in this study module. The description of the concept can be clearly seen in the first and second sessions. At this session the students will be briefed on some concepts through LS-CBT activities, problem analysis and problem solving that are also combined with 'goal setting' which is one of the applications in CBT while in the second session the students are also exposed to $A B C$ situations and identities rational and irrational beliefs.

In the next phases of understanding the Image phase it is a good idea for students to be taught or demonstrated to do a task to be implemented. It is important for students to get the real picture of how to do the activities that will be implemented. Actually this Phase of Understanding covers all activities that require a demonstration from a mentor to the students.

The Practical Understanding Phase is the most important phase in this study as this phase is the training phase that is being carried out to the students. In this phase the students will be exposed to the exercises as they are in the module. The students will go through seven sessions in this phase, starting from the third session to the ninth session. In the third session, students will enter a self-motivation session combined with Relaxation techniques first. The fourth session involves self-management and time management using provocative methods. In the fifth session, the students will go through a process of Mastering the Vocabulary combined with word processing. The sixth session involves the listening skills and at the end of the session the students are required to make an analysis on the advantages and disadvantages of activities performed through 'locusts and loaves' activities. The seventh activity involves recording notes and followed by correction of information while learning skills from textbooks combined with confrontational techniques at the eighth session and in the ninth session saw the final skills of the Exam Skills using Decision-Making Techniques. 
The next phase is Understanding Experience Quiz. At this session, students are asked to state the experience gained during the program. Students are also asked to state the strengths and weaknesses they have encountered and renewed during the activity in the group. In this session, students will also have the experience from the results of the activities performed and the results of this experience can be identified through the work done.

After going through all the sessions, the students will be given the final test (post-test) aimed in obtaining information regarding the level of understanding and achievement of the students in the training being conducted, the appointed counselor will make a summary of all the activities that the participants have gone through and if they are appropriate to the students, they will also be asked to draw conclusions. 
Conceptual Framework of The Learning group cluster module-CBT Approach the large group intervention of the Learning Skills Module and the Small Group of Learning Skills Modules

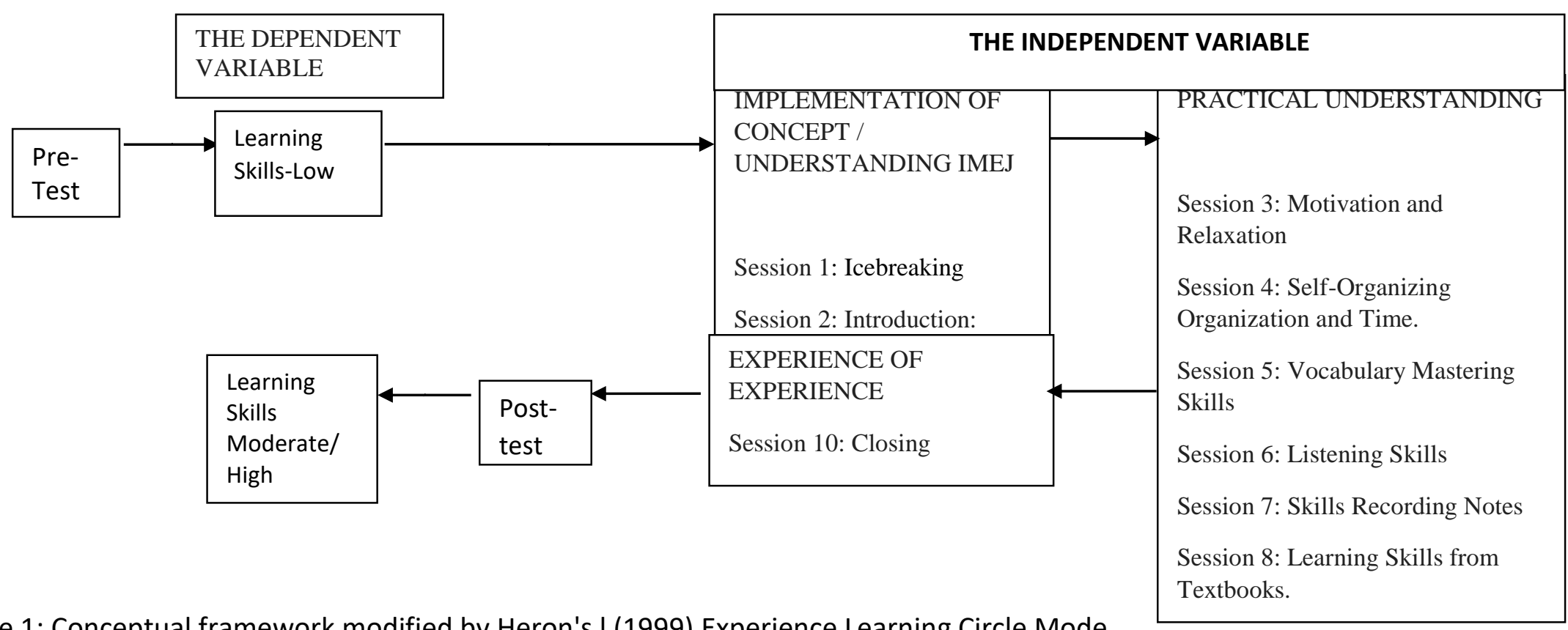

Figure 1: Conceptual framework modified by Heron's I (1999) Experience Learning Circle Mode. 
INTERNATIONAL JOURNAL OF ACADEMIC RESEARCH IN BUSINESS AND SOCIAL SCIENCES

Vol. 9, No. 3, March, 2019, E-ISSN: 222 2-6990 ¿ 2019 HRMARS

\section{Methodology}

The purpose of this study is to examine the effectiveness of the Small Group Guided Learning Skills Module (SGGL) on self learning and achievement skills. Experimental studies were conducted using pre-test and post-test designs to treatment groups and control groups such as descriptions in Table 1 below.

Table 1: Experimental study using Pre-test and Post-test designs on treatment groups and control groups

\begin{tabular}{cccc} 
Jenis Group & Pre-test & $\begin{array}{c}\text { Intervension } \\
\text { Group }\end{array}$ \\
\hline Group R1 & & X1 & 02 \\
Group R1a & 01 & X1 & 02 \\
Group R1b & 01 & X1 & 02 \\
Group R1c & 01 & & 02 \\
Group K1 & 01 & & 02 \\
\hline
\end{tabular}

Key Note:

R1 = SGGL (3 Treatment Groups R1a, R1b and $\quad X \quad=$ Intervension Study Skills Group R1c)

$01=$ Pre-test

1 Module

$\mathrm{K} 1$ = Control Group

$\mathrm{X}=$ Intervension Study Skills Group

2 Module

0 = Post-test

2

Source: Mohammad Aziz Shah (2010) modified from Heppner, Kivlighan dan Wampold (1992)

\section{Research Decision}

This chapter discusses matters related to the results of the study. Included in this chapter is the findings of statistical analysis as a result of the study on the effectiveness of the Learning Skills Small Group conducted against the control group. The results of the study are quantitatively presented (experimental) through the measurement of pre-test data and post-test for the HM Stusy skills questionnaires that have been administered on treatment groups and control groups. The presentation of the results of the study was conducted in two parts, namely the results of the analysis of the pre-test data of the experiment and the test of the Hypothesis data of the study. 
INTERNATIONAL JOURNAL OF ACADEMIC RESEARCH IN BUSINESS AND SOCIAL SCIENCES

Vol. 9, No. 3, March, 2019, E-ISSN: 222 2-6990 @ 2019 HRMARS

Table 2: Summary The statistical analysis measures the mean score difference between the SmallGroup Guided Learning and the control group based on the overall subject pre-test data.

\begin{tabular}{|l|l|l|}
\hline Groups & & Study Skills \\
\hline SmallGroup Guided Learning & Mean & 2.7587 \\
\cline { 2 - 3 } & $\mathrm{N}$ & 30 \\
\cline { 2 - 3 } & Standard deviation & 0.34654 \\
\hline \multirow{4}{*}{ Control Group } & Mean & 2.6369 \\
\cline { 2 - 3 } & $\mathrm{N}$ & 60 \\
\cline { 2 - 3 } & Standard deviation & 0.22667 \\
\hline \multirow{3}{*}{ Whole } & Mean & 2.7036 \\
\cline { 2 - 3 } & $\mathrm{N}$ & 120 \\
\cline { 2 - 3 } & Standard deviation & 0.29558 \\
\hline
\end{tabular}

$p<.0 .05$ (significant at $95 \%$ level)

Based on Table 2, the details indicate that there is no significant difference in pre-test data for both groups of SmallGroup Guided Learning and control groups. The mean score and the standard deviation of the two groups with the learningh skills variables clearly did not show a significant difference as the subjects were composed of students who had a moderate score in the concept of learning skills. This is evident in all the mean data set forth in the pre-test for learning skills ie 2.76 for SmallGroup Guided Learning and 2.64 for the control group while for the overall mean of learning skills is 2.70 .

The conclusions of the above analysis clearly demonstrate that the overall learning skill mean that there is no significant difference.

\section{Hypothesis Testing}

Testing of hypotheses and the results of the study are arranged regularly in accordance with the established Hypothesis arrangements. In this study there are 2 hypotheses that are used to analyze the effect of the treatment on the dependent variable and to study the effects of the type of treatment on the dependent variable.

\section{Hypothesis Null 1}

There was no significant difference in pre-test min size and post-test variables bound Learning Skills Study of treatment compared to the control group.

This section is devoted to testing the effects of treatment on dependent variables. The built-in hypothesis is used to test each variable in terms of treatment effectiveness and the effectiveness of the type of treatment group received. Therefore, for this type of analysis, MANOVA analysis is used. The results of the pre and post-test analysis of the main variables of the study can be seen in the diagram below ie Table 2. It is a summary of the descriptive analysis of pre-test min score and posttest of the main boundary variable as a whole. 
INTERNATIONAL JOURNAL OF ACADEMIC RESEARCH IN BUSINESS AND SOCIAL SCIENCES

Vol. 9, No. 3, March, 2019, E-ISSN: 222 2-6990 @ 2019 HRMARS

Table 2 Summary of descriptive analysis of pre-test min score and post-test of major dependent variable as a whole

\begin{tabular}{lccl}
\hline Variables & \multicolumn{2}{c}{ Mean } & Description \\
\cline { 2 - 3 } & Pre-test & Post-test & \\
\hline Study Skills & 2.6548 & 3.7036 & Increased \\
\hline
\end{tabular}

The summary of the MANOVA Test conducted shows that the significant difference of Learning Skills Learning group vs. control group. This clearly shows that the effect of treatment influences this study and is found to be an improvement over the main variables ie learning skills to rise from medium to high level ie for primary learning skills (pre-test $=2.6548$ moderate to post-test = 3.7036; high level ) which is more than 3.61 Kerlinger (1979) ie above 3.61 Kerlinger (1979). Based on the results of the above study, SmallGroup Guided Learning is overall effective in increasing KB's main tied variable.

For a more detailed result, a summary of descriptive analysis of the pre-test min score and Study skills main dependent variable tests were analyzed using the comparison based on the SmallGroup Guided Learning treatment (consisting of 3 groups of R1a, R1b and R1c), and Control group (K1) as shown in Table 3

\section{Null Hypothesis 1}

There is no significant difference in pre-test min and post-dependent variable tests ie experimental group KB compared to control group.

Table 3: $\quad$ Summary of descriptive analysis of pre-test min score and post-dependent variabledependent tests based on groups within the subject

\begin{tabular}{|c|c|c|c|c|}
\hline \multirow[t]{2}{*}{ Variables } & \multirow[t]{2}{*}{ Groups } & \multicolumn{2}{|c|}{ Mean } & \multirow[t]{2}{*}{ Description } \\
\hline & & Pre-test & Post-test & \\
\hline $\begin{array}{l}\text { Study } \\
\text { Skills }\end{array}$ & $\begin{array}{l}\text { Small treatment } \\
\text { Group } \\
\text { R1a } \\
\text { R1b } \\
\text { R1c } \\
\text { K1-Control Group }\end{array}$ & $\begin{array}{l}2.6476 \\
(.22013) \\
2.6469 \\
(.24099) \\
2.6619 \\
(.19304) \\
2.6381 \\
(.24585) \\
2.6925 \\
(.30156)\end{array}$ & $\begin{array}{ll}3.7690 & (.24737) \\
3.8381 & (.28279) \\
3.7905 & (.28567) \\
3.6786 & (.14385) \\
2.6385 & (.28225)\end{array}$ & $\begin{array}{l}\text { Increased } \\
\text { Increased } \\
\text { Increased } \\
\text { Increased } \\
\text { Decreased }\end{array}$ \\
\hline
\end{tabular}

Description (.) = standard deviation

Based on Table 3 above, a summary of the descriptive analysis of the pre-test min score and the main dependent variable post-test based on the group among the subjects found that the two major groups of study variables ie study skills are seen in terms of the small treatment group R1a increase from pre-test $(2.6469=$ moderate level $)$ to a high level of 3.8381 on post-test. For R1b it was 
INTERNATIONAL JOURNAL OF ACADEMIC RESEARCH IN BUSINESS AND SOCIAL SCIENCES

Vol. 9, No. 3, March, 2019, E-ISSN: 222 2-6990 @ 2019 HRMARS

found that the increase was also obtained from the pre-test $(2.6619=$ moderate level $)$ to the high level of 3.7095 in the post-test, for R1c it shows an increase ie from pre-test $(2.6381=$ moderate level) ie 3.6786 on post-test and also on test on R2 which still showed improvement from pre-test ( $2.7817=$ moderate level) to high level of 3.6730 on post-test while K1 control group did not show increase but decrease from pre - Test $(2.6925=$ moderate level) to the same level ie moderate and even decreased by 2.6385 on post-test.

\section{Null Hypothesis 1.1}

There was no significant difference in pre-test min size and subscale tests of Self Motivation, SelfManagement and Time, listening skills, Mastering the Vocabulary, note-taking skills, learning skills from textbooks, and Examination Skills compared to the control group.

Table 4 Summary of descriptive analysis of pre-test mean scores and post-test dependent variables subscale Learning Skills for study skills questionnaires based on clusters among subjects

\begin{tabular}{|c|c|c|c|c|}
\hline \multirow[t]{2}{*}{ Variables } & \multirow{2}{*}{ Groups } & \multicolumn{2}{|c|}{ Mean } & \multirow{2}{*}{ Description } \\
\hline & & Ujian Pra & Ujian Post & \\
\hline $\begin{array}{l}\text { Self } \\
\text { Motivation }\end{array}$ & $\begin{array}{l}\text { Small treatment Group } \\
\text { R1a } \\
\text { R1b } \\
\text { R1c } \\
\text { K1-Control Group }\end{array}$ & $\begin{array}{ll}2.5278 & (.33757) \\
2.6500 & (.25398) \\
2.8167 & (.27722) \\
2.7167 & (.45846) \\
2.7667 & (.42431)\end{array}$ & $\begin{array}{ll}3.7389 & (.46462) \\
3.8167 & (.56355) \\
3.6833 & (.29659) \\
3.6167 & (.29450) \\
2.6528 & (.43644)\end{array}$ & $\begin{array}{l}\text { Increased } \\
\text { Increased } \\
\text { Increased } \\
\text { Increased } \\
\text { Decreased }\end{array}$ \\
\hline $\begin{array}{l}\text { Self- } \\
\text { Management } \\
\text { and Time }\end{array}$ & $\begin{array}{l}\text { Small treatment Group } \\
\text { R1a } \\
\text { R1b } \\
\text { R1c } \\
\text { K1-Control Group }\end{array}$ & $\begin{array}{ll}2.6778 & (.32734) \\
2.7333 & (.42455) \\
2.7000 & (.35832) \\
2.6000 & (.16102) \\
2.6750 & (.36363)\end{array}$ & $\begin{array}{l}3.7611(.43436) \\
3.6500(.41611) \\
2.6500(.32820) \\
3.6833(.55805) \\
2.5667(.37607)\end{array}$ & $\begin{array}{l}\text { Increased } \\
\text { Increased } \\
\text { Decreased } \\
\text { Increased } \\
\text { Decreased }\end{array}$ \\
\hline $\begin{array}{l}\text { Listening } \\
\text { skills }\end{array}$ & $\begin{array}{l}\text { Small treatment Group } \\
\text { R1a } \\
\text { R1b } \\
\text { R1c } \\
\text { K1-Control Group }\end{array}$ & $\begin{array}{ll}2.5889 & (.47693) \\
2.5000 & (.64788) \\
2.5833 & (.23895) \\
2.6833 & (.48718) \\
2.6556 & (.44135) \\
\end{array}$ & $\begin{array}{ll}3.6267 & (.38194) \\
3.7500 & (.38690) \\
3.6500 & (.41907) \\
2.4500 & (.30480) \\
2.6611 & (.37952) \\
\end{array}$ & $\begin{array}{l}\text { Increased } \\
\text { Increased } \\
\text { Increased } \\
\text { Decreased } \\
\text { Increased } \\
\end{array}$ \\
\hline $\begin{array}{l}\text { Mastering } \\
\text { the } \\
\text { Vocabulary }\end{array}$ & $\begin{array}{l}\text { Small treatment Group } \\
\text { R1a } \\
\text { R1b } \\
\text { R1c } \\
\text { K1-Control Group }\end{array}$ & $\begin{array}{ll}2.4056 & (.37057) \\
2.4500 & (.35180 \\
2.3500 & (.41907) \\
2.4167 . .(.37060) \\
2.5139 & (.54053)\end{array}$ & $\begin{array}{ll}3.7389 & (.45630) \\
3.6500 & (.62853) \\
3.6100 & (.41722) \\
2.3667 & (.23307) \\
2.5806 & (.45977) \\
\end{array}$ & $\begin{array}{l}\text { Increased } \\
\text { Increased } \\
\text { Increased } \\
\text { Decreased } \\
\text { Increased }\end{array}$ \\
\hline $\begin{array}{l}\text { Note-taking } \\
\text { skills }\end{array}$ & $\begin{array}{l}\text { Small treatment Group } \\
\text { R1a } \\
\text { R1b } \\
\text { R1c }\end{array}$ & \begin{tabular}{|ll}
2.6000 & $(.34905)$ \\
2.6667 & $(.32394)$ \\
2.5833 & $(.47394)$ \\
2.5500 & $(.23636)$ \\
\end{tabular} & $\begin{array}{ll}3.6889 & (.45006) \\
3.8667 & (.51400) \\
3.7333 & (.38650) \\
3.6467 & (.38329) \\
\end{array}$ & $\begin{array}{l}\text { Increased } \\
\text { Increased } \\
\text { Increased } \\
\text { Increased }\end{array}$ \\
\hline
\end{tabular}


INTERNATIONAL JOURNAL OF ACADEMIC RESEARCH IN BUSINESS AND SOCIAL SCIENCES Vol. 9, No. 3, March, 2019, E-ISSN: 222 2-6990 @ 2019 HRMARS

\begin{tabular}{|c|c|c|c|c|}
\hline & K1-Control Group & $2.6556(.44348)$ & $2.6194(.41748)$ & Decreased \\
\hline $\begin{array}{l}\text { Learning } \\
\text { skills from } \\
\text { textbooks }\end{array}$ & $\begin{array}{l}\text { Small treatment Group } \\
\text { R1a } \\
\text { R1b } \\
\text { R1c } \\
\text { K1-Control Group }\end{array}$ & $\begin{array}{l}2.6722(.37520) \\
2.8333(.39284) \\
2.6667(.30429) \\
2.5167(.38849) \\
2.6306(.35798) \\
\end{array}$ & $\begin{array}{ll}3.7667 & (.34016) \\
3.6167 & (.29450) \\
2.4167 & (.36218) \\
3.6673 & (.34066) \\
2.5472 & (.35534) \\
\end{array}$ & $\begin{array}{l}\text { Increased } \\
\text { Increased } \\
\text { Decreased } \\
\text { Increased } \\
\text { Decreased }\end{array}$ \\
\hline $\begin{array}{l}\text { Examination } \\
\text { Skills }\end{array}$ & $\begin{array}{l}\text { Small treatment Group } \\
\text { R1a } \\
\text { R1b } \\
\text { R1c } \\
\text { K1-Control Group }\end{array}$ & $\begin{array}{ll}2.5736 & (.38110) \\
2.7040 & (.19523) \\
2.9333 & (.54546) \\
2.9833 & (.28814) \\
2.9083 & (.48365)\end{array}$ & $\begin{array}{ll}3.6100 & (.56494) \\
3.9333 & (.68584) \\
3.6833 & (.49969) \\
2.8833 & (.34292) \\
2.7250 & (.46011) \\
\end{array}$ & $\begin{array}{l}\text { Increased } \\
\text { Increased } \\
\text { Increased } \\
\text { Decreased } \\
\text { Decreased }\end{array}$ \\
\hline
\end{tabular}

Descrition: (.) = standard deviation

Based on Table 4 above, the summary of the descriptive analysis of the pre-test min score and the main dependent variable postings based on the cohort among the subjects found that the main variables of the Self Motivation, Self-Management and Time, listening skills, Mastering the Vocabulary, note-taking skills, learning skills from textbooks, and Examination Skills

For Self Motivation where it is seen in terms of R1a small treatment group showed an increase from pre-test $(2.6500=$ moderate level) to a high level of 3.8167 on post-test. For R1b it was found that the increase was also obtained from pre-test (2.8167 = moderate level) to a high level of 3.6833 on post-test, for R1c it was still showing an increase ie from pre-test $(2.7167=$ moderate level) ie 3.6167 on post-test and also on test on R2 which still showed improvement from pre-test $(2.8444=$ moderate level) to high level of 3.6389 on post-test while $\mathrm{K} 1$ control group did not show increase but decreased from pre - testing $(2.7667=$ moderate level) to the same level ie moderate and even decreasing ie 2.6528 on post-test.

For Self-Management and Time management, in terms of R1a small treatment group showed improvement from pre-test $(2.7333=$ moderate level) to high level of 3.6500 on post-test. For R1b it was found that there was a decrease in the pre-test $(2.7000=$ moderate level $)$ at the same level of 2.6500 on the post-test, R1c it was still showing an increase ie from pre-test $(2.6000=$ moderate level) high level of 3.6833 on post-test and so on test on R2 which still showed improvement from pre-test ( $2.7333=$ moderate level) to high level of 3.6611 on post-test while $\mathrm{K} 1$ control group did not show increase and decreased from pre-test $(2.6750=$ moderate level $)$ to the same level ie moderate and even decreased by 2.5677 on post-test.

For Listening skills where as seen in terms of R1a small treatment group showed an increase from pre-test $(2.5000=$ moderate level $)$ to high level of 3.7500 on post-test. For R1b it was found that there was a decrease in pre-test $(2.5833=$ moderate level) to a high level of 3.6500 in post-test, for $\mathrm{R} 1 \mathrm{c}$ it was still shown that the pre-test $(2.6833=$ moderate level) the same as 2.4500 on post-test and the same test with R2 which still showed improvement from pre-test $(2.7333=$ moderate level) to high level of 3.6611 on post-test while $\mathrm{K} 1$ control group did not show an increase but decreased from pre-test $(2.6750=$ moderate level $)$ to the same level ie moderate and even decreased by 2.5677 on post-test. 
For Mastering the Vocabulary, if seen in terms of R1a small treatment group showed improvement from pre-test $(2.4500=$ moderate level) to high level of 3.6500 on post-test. For R1b it was found that there was a decrease in the pre-test $(2.3500=$ moderate $)$ to the high of 3.6100 on the post-test, for R1c it was still lower than the pre-test $(2.4167=$ moderate level) the same 2.3667 on the post-test and the tests on R2 which still showed improvement from pre-test (2.6167 = moderate level) to the high level of 3.6389 on the tests while the K1 control group showed a slight increase but still on a moderate level of pre-test $(2.5139=$ medium level) to the same level of moderate 2.5806 on post-test.

For Note-taking skills, if seen in terms of R1a small treatment group showed an increase from pre-test $(2.6667=$ moderate level) to a high level of 3.8667 on post-test. For R1b it was found that there was an increase in pre-test $(2.5833=$ moderate level) to a high level of 3.7333 in post-test, for $\mathrm{R} 1 \mathrm{c}$ it was still showing an increase ie from pre-test $(2.5500=$ moderate level) high at 3.6467 on posttest and likewise with R2 test which still showed a decrease from pre-test (2.8778 = moderate level) to moderate level of 3.6889 on post-test while $\mathrm{K} 1$ control group did not show decline even lower than that pre-test $(2.6556=$ moderate level $)$ to the same level ie medium and even decreased by 2.6194 on post-test.

Learning skills from textbooks found that there was a decrease in the pre-test $(2.6667=$ moderate level) to the same 2.4167 on the post-test, for R1c it was still showing an increase ie from pre-test $(2.5167=$ moderate level $)$ high at 3.6673 on post-test and also on test on $\mathrm{R} 2$ which still showed improvement from pre-test $(2.6778=$ moderate level) to high level of 3.6667 on post-test while control group $\mathrm{K} 1$ decreased ie from pre-test ( $2.6306=$ moderate level) to the same level ie moderate and even decreased by 2.5472 on post-test.

For Examination Skills, where, in terms of the R1a small treatment group showed an increase from pre-test $(2.7040=$ moderate level) to a high of 3.9333 on post-test. For R1b it was found that there was an increase in pre-test $(2.9333=$ moderate level) to the high of 3.6833 on the post-test, for R1c it was still showing a decrease ie from pre-test ( $2.9833=$ moderate level) high of 2.8833 on posttest and so on test on R2 which still showed improvement from pre-test $(2.9500=$ moderate level) to high level of 3.6100 on post-test while control group K1 decreased from pre-test ( 2.9083 = moderate level) to the same level ie moderate even decreased ie 2.7250 on post-test.

\section{Conclusion}

Referring to MANOVA Analysis, the results of the study proved that there was no significant difference between the test min score on the Null Hypothesis constructed against all the major boundary variables in the study skills among the for Small Group Guided Learning, and control groups. The results also show that the group of cognitive grouping of learning skills, Small Group Guided Learning of Cognitive Behavioral Therapy learning group has the effect on the improvement of learning skills boundary variables among middle-aged adolescents who have moderate level of learning skills.

If viewed in terms of the context of the theoretical study and the constitutional study it aims to increase the level of students' control over understanding and increase the level of skill learning skills and improve their level of performance in life based on the existing knowledge available to the 
students. Therefore, self motivation (SM), self-management (STM), listening skills (LS), mastering vocabulary (MV), note-taking skills (NTS), learning skills from textbooks (LSFT), and Examination Skills (ES) based based on the comparison between the treatment group and the control group. Existing knowledge of the students regarding learning skills can be enhanced and this is evident from the results of the study that shows that learning skills with group treatment increased significantly after undergoing treatment process compared with those in the control group.

\section{References}

Atkinson, J. W. \& Raynor. J. O. (1974) Motivation and Achievement. Winston, New York. Barker, L. L. (1971) Listening Behavior. Prentice-Hall, Inc., Englewood Cliffs, New Jersey. Branch, R., \& Willson, R. (2010) Cognitive Behavioral Therapy for Dummies $2^{\text {nd }}$ Edition.John Wiley \& Sons, Ltd. Publication, England.

Brunner, J. T., \& Hudson, M, S. (2014b) Hm Program Student Text: Learning and study skills Program $4^{\text {th }}$ Ed., Rowman \& Littlefield, Maryland.

Cresswell, J. W. \& Miller, D.J. (2000). Determining validity in qualitative inquiry. Theory into Practice.

Drucker, P. F. (1966) The effective executive, Oxford: Butterworth-Heinemann Ltd.

Heppner, P. P., Kivlighan, D.M. Jr. \& Wampold, B.E. (1992) Research design in counseling. Pasific Grove CA: Brooks/ Cole Pub. Company.

Heron, J., (1999) The Complete Facilitator's Hand Book, Kogan Page Limited: London.

Macan, T. H., Shahani, C., Dipboye, R. L., \& Phillips, A. P. (1990). College students' time management: Correlations with academic performance and stress. Journal of Educational Psychology.

McClelland, D. C. (1961) The achieving society, Princeton, Van Nostrand.

McClelland, D. C. (1965) An achievement and enterpernuership: A longitudunal study, Journal of Psychology.

McClelland, D. C. (1985) Human motivation, Scot, Foresman \& Company, USA.

McCrimmon, J.M. (1976) "Writing As a Way of Knowing." In the promise of English: NCTE Distinguished Lectures. Urbana, I II. National Council of Teachers of English.

Arip, M. A. S. M. (2010), Tesis Phd. Group impacts guidance on the concept of self, endurance and adolescent adolescence, Universiti Kebangsaan Malaysia. Bangi, Kuala Lumpur.

Muchnick, C. C. \& Muchncik, R. M. (2011) Guide to study skills, Advantage Quest Publication, Petaling Jaya.

Robinson, F. P. (1946). Effective study. New York: Harper.

Robinson, F. P. (1978). Effective Study (6th ed.). New York: Harper \& Row.

West Virginia Department (2015) WVAdultEd Instructor Handbook 2016-17 Section 5: I Identifying strengths and weaknesses, adult education (AdultEd) program office of Adult Education and Workforce Development, West Virginia Department of Education, West Virginia.

Wilenzick, P. G. (1990). Hm Study Skills Inventory. Reston, Newton, MA: NSSP/ NAESP Publication. 